\title{
Role-Based Leadership Grounded Theory
}

\section{Gotsdanker A*}

Department of Psychology, Walden, University, Israel

*Corresponding author: Aryeh Gotsdanker, Department of Psychology, Walden University, Israel, Tel: +972546598989; E-mail: gotsdanker@gmail.com Received date: June 01, 2018; Accepted date: June 11, 2018; Published date: June 16, 2018

Copyright: (C) 2018 Gotsdanker A. This is an open-access article distributed under the terms of the Creative Commons Attribution License, which permits unrestricted use, distribution, and reproduction in any medium, provided the original author and source are credited.

Citation: Gotsdanker A (2018) Role-Based Leadership Grounded Theory. Arts Social Sci J 9: 378. doi:10.4172/2151-6200.1000378

Keywords: Leadership; Assigned leaders; Elected leaders; Role-based leadership

\section{Perspective}

Existing for today leadership theories don't provide clear understanding of leadership phenomenon and it is not a scientific term with a formal, standardized definition [1]. The theories are discussing all aspects of leadership from the "Great man", to charismatic leaders' divine inspiration of followers. Scholars investigated personality traits of best leaders, developed situational theory, and most discussed till today Transactional-Transformational Leadership theory [2-6]. All of these theories looped round but we still have no consistent definition of the leadership phenomenon and no answer on the core questionwhy subordinates following the leader? Currently this question is answered similarly as century before. At Carlyle's time it was divine inspiration, today it is inspiration motivation of followers [6]. If inspiration is key leading power, how to bag inspiration? Is it possible to lead without inspiration? Is it possible to lead by simple punishment and reward strategy as described in transactional leadership theory? How to distinct persuasion techniques, stereotypes, paid labor practice from pure leadership power?

Question: What is the core power of the leader which allows him to lead and direct others?

Main problem of this study is over mixing of the leadership phenomenon. Leaders could use social influence technics which are well studied by social psychologist: the Milgram Obedience Experiment, Asch Conformity Experiment, Stanford Prison Experiment [7-9]. Persuasion technics could also been used in leading and directing others, for example: Cognitive Dissonance Theory, Lowball, Foot-in-the-door, and number of technics, described in the Cialdini's book of influence $[10,11]$. Data from researches, performed in the organizational settings, erodes by paid labor nature of organizations, mixing management and leadership, formal power and orders. Getting answer on this research question will help scientific community distinguish core leadership phenomenon for the further investigating and conceptualization.

\section{Method}

\section{Stage 1: Existing theories}

Most cited leadership theories will be researched and coded accordantly to mixed influence and persuasion phenomenon. All founded codes would be categorized by classic studies on influence and persuasion topics. Uncategorized codes would be analyzed more detailed to find out core leadership influence. At this stage we will have a diagram with overlapping cycles and would be able to narrow our research focus.

\section{Stage 2: Distinguish from labor organizations}

On this stage I will try to investigate leadership not in business or academic setting. To eliminate factors such formal authority and paid hierarchical structure. For this purpose I am going to use a gaming community, for example World of Warcraft, where gamer's voluptuary join teams (guilds) and following guild leaders. The study is going to be in form of survey with several closed questions such role (leader or follower), maturity, experience and control questions-age, gender. Main survey question would be open-ended-please describe your experience in team playing, why you joining a guild and what is your benefit of following (or directing) others. By coding and categorizing answers I will have some ideas of core meaning of leadership for followers and leaders.

\section{Stage 3: Knowledge from ethology}

Last data set for the grounded theory study I chose social organizations from animal world. By analyzing and categorizing knowledge of purpose of leadership in animal social organization I hope I could update my understanding of the complex phenomenon and by extrapolating these findings back to the human organizations I'll have a chance to finalize the theory.

\section{References}

1. Vroom VH, Jago AG (2007) The role of the situation in leadership. American psychologist 62: 17-24.

2. Carlyle T, Gosse E (1896) On heroes and hero worship and the heroic in history. London; New York: Ward, Lock \& Bowden.

3. Weber M, Henderson AM, Parsons T (1947) Max Weber, the theory of social and economic organization. Glencoe, Ill.: Free Press \& The Falcon's Wing Press.

4. Stogdill RM (1948) Personal factors associated with leadership; a survey of the literature. J Psychol 25;35-71

5. Hersey P, Blanchard KH (1969) Management of organizational behavior : Utilizing human resources. Englewood Cliffs, N.J.: Prentice-Hall.

6. Bass B(1985) Leadership and performance beyond expectations: Collier Macmillan.

7. Milgram S (1963) Behavioral Study of obedience. The Journal of Abnormal and Social Psychology 67: 371-378.

8. Asch SE (1956) Studies of independence and conformity: I. A minority of one against a unanimous majority. Psychological Monographs: General and Applied 70: 1-70.

9. Zimbardo PG, Cross AB (1971) Stanford prison experiment: Stanford University. 
Citation: Gotsdanker A (2018) Role-Based Leadership Grounded Theory. Arts Social Sci J 9: 378. doi: 10.4172/2151-6200.1000378

Page 2 of 2

10. Festinger L, Carlsmith JM (1959) Cognitive consequences of forced 11. Cialdini RB (2009) Influence: HarperCollins. compliance. The Journal of Abnormal and Social Psychology 58: 203. 